AN INTRODUCTION TO SHAKESPEARE 


\title{
An Introduction to Shakespeare
}

The Dramatist in His Context

\author{
Peter Hyland
}

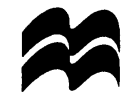

Macmillan Education 
SBN 978-0-333-59880-1

ISBN 978-1-349-24952-7 (eBook)

DOI 10.1007/978-1-349-24952-7

AN INTRODUCTION TO SHAKESPEARE

Copyright (C) 1996 by Peter Hyland

Softcover reprint of the hardcover 1st edition 1996

All rights reserved. No part of this book may be used or reproduced in any manner whatsoever without written permission except in the case of brief quotations embodied in critical articles or reviews.

For information, address:

St. Martin's Press, Scholarly and Reference Division, 175 Fifth Avenue, New York, N.Y. 10010

First published in the United States of America in 1996

ISBN 978-0-312-16274-0 (cloth)

ISBN 978-0-312-16276-4 (paperback)

Library of Congress Cataloging-in-Publication Data

Hyland, Peter.

An introduction to Shakespeare : the dramatist in his context /

Peter Hyland.

p. $\mathrm{cm}$.

Includes bibliographical references ( $\mathrm{p} . \quad$ ) and index.

ISBN 978-0-312-16274-0 (cloth) - ISBN 978-0-312-16276-4 (pbk.)

1. Shakespeare, William, 1564-1616-Stage history-To 1625.

2. Shakespeare, William, 1564-1616 - Contemporary England.

3. Theater-England-History-16th century. 4. Theater-England-History - 17th century. 5. England-Civilization-16th century.

6. England-Civilization-17th century. I. Title.

PR3095.H95 1996

822.3 '3-dc20

96-19741

CIP 


\section{Contents}

Prefatory Note vii

Introduction: Approaching Shakespeare and His Stage 1

1 Life and Times 17

Life $\quad 7$

Shakespeare's Context $\quad 19$

Politics and History 21

Social Models $\quad 29$

London 36

Beliefs and Myths 39

2 Theatrical Professions $\quad 55$

The Rise of Playing 56

The Professional Public Theatre 63

The Playhouses $\quad 74$

Actors and Acting $\quad 80$

Playwrights $\quad 87$

Audiences $\quad 89$

Control and Censorship 93

3 The Plays 97

Canon, Texts and Chronology $\quad 97$

Sources and Materials 107

Language and Style $\quad 111$

Drama and Metadrama 121

Criticism and 'Meaning' 127

Genre 131

Comedies $\quad 134$

Histories 161

$\begin{array}{ll}\text { Tragedies } & 182\end{array}$

Notes 202

Chronology 206

Suggested Reading 207

Index 211 
For Theresa 


\section{Prefatory Note}

Dr Johnson once wrote, 'Notes are often necessary, but they are necessary evils.' Anyone who writes about Shakespeare has inherited a vast amount of knowledge, and it is impossible to assign all of it to its original source. I have tried to keep to a minimum my own footnotes by acknowledging only direct quotation or citation, but all the sources I have used are to be found in the 'Suggested Reading' list.

I have quoted throughout from the New Arden editions of Shakespeare's plays, published by Routledge. Documentary matter taken from E.K. Chambers, The Elizabethan Stage (Oxford: Clarendon Press, 1923 ) is noted in the text, using the abbreviation ES and volume and page numbers. In the interests of consistency I have modernized spelling when appropriate.

P.H. 